\title{
- Causal Factors of Unwanted Fertility in India's Easternmost Border State Manipur
}

\author{
N. Sharat Singh ${ }^{1}$, Kh. Sundari Devi ${ }^{2}$ \\ 'Department of Statistics, D. M. College of Science, Imphal (India); ${ }^{2}$ Research Scholar, Department of Statistics, CM] University, Meghalaya.
}

ection: Healthcare

ISI Impact Factor

(2019-20): 1.628

IC Value (2019): 90.81 $\operatorname{SJIF}(2020)=7.893$

(c) (i) (8)

Copyright@IJCRR

\section{ABSTRACT}

Introduction: Unwanted fertility is a serious problem in achieving a stable population in India particularly in backward regions.

Aim: The study is to examine the determinants of unwanted fertility in tribal-dominated valley areas of Manipur, Indian easternmost state internationally bordering Myanmar.

Materials and Methods: A cross-sectional study of 1152 currently married women of age below 52 years was conducted under a cluster sampling scheme from May 2018 to April 2019. Logistic regression along with classical $\mathrm{t}$ - statistics explores the risk factors of unwanted fertility.

Result: The fertility of tribal women (3.1) is significantly higher $(P<0.01)$ than non-tribal (2.6). Low education $(P<0.01)$, sex of $2 n d$ birth $(P<0.05)$ and son preference $(P<0.01)$ have been detected to be major causes of unwanted births.

Conclusion: To save and control unwanted human births in backward regions of Manipur, son preference is needed to be eliminated and also the education of couples may be enhanced.

Key Words: Tribal, Odds ratio, Third birth, Education, Son preference

\section{INTRODUCTION}

In India, higher fertility of tribal women is associated with low socioeconomic status, disadvantages of communication, poor infrastructures etc. ${ }^{1,2}$ Even after seven decades of national population policy (NPP-2000), fertility rates are higher for women in disadvantaged groups say for instance 2.5 children per women among scheduled tribes, 2.3 among scheduled castes, and 2.2 among other backward classes, compared with women who are not any of these groups (2.4 children) while all India figure of $2.2{ }^{3}$ Meanwhile, nationally unwanted fertility of $3^{\text {rd }}$ birth transition is a serious demographic problem to population growth. Lack of education and son preference may be solely responsible for it. In India, son preference may be due to three major factors - economic, socio-cultural and religious utilities. ${ }^{4}$ In the patriarchal system of the family son is very important for the continuation of the family in the society and also religious functions that only sons can provide. ${ }^{5}$ In the case of intention, about $19 \%$ of Indian couples want more sons

\section{Corresponding Author:}

Dr. N. Sharat Singh, Department of Statistics, D. M. College of Science, Imphal - 795001 (India)

Email: sharatstats65@gmail.com

ISSN: 2231-2196 (Print) ISSN: 0975-5241 (Online)

Received: $18.02 .2021 \quad$ Revised: 15.04 .2021

Accepted: 23.05 .2021

Published: 24.10 .2021

than daughters, but only 3 to $4 \%$ of them want more daughters than sons. ${ }^{3}$ While, the wanted fertility rate in the country is 1.8 children (defined by the ideal number of children at an average for a couple) in 2015-16 which is almost the same as 1.9 in 2005-06. However, the gap between the actual and wanted fertility rates is declined by half say from 0.8 in 2005-06 to 0.4 in 2015-16. But only five states Meghalaya (2.8), Bihar (2.5), Manipur (2.3), Nagaland (2.3) and Mizoram (2.2) have wanted fertility rates above the national goal of replacement fertility level (2.1). In Manipur, $24.6 \%$ of ever-married women want more sons than daughters in 2015-16 which is declining from 31.2 in $2005-06 ; 36.5 \%$ in $1998-99$ and $43.4 \%$ in $1992-93.3,6$

The present study is thus carried out to examine the status of varied fertility indicators and determinants of unwanted fertility in tribal-dominated areas of rural Manipur valley to identify risk/causal factors in achieving the national sociodemographic goal for replacement fertility (2.1) or so-called nationally wanted fertility level. There are more than 33 scheduled tribes with about $30 \%$ of the total population in 
Manipur having a unique feature that it has the largest number of dialects with the least population.

\section{MATERIALS AND METHODS}

A cross-sectional as well as community-based study of 1152 currently married women (tribal: $50 \%$ and non-tribal: $50 \%$ ) of age below 52 years was conducted through a cluster sampling scheme in four valley districts of Manipur - Bishnupur, Imphal East, Imphal West and Thoubal during May 2018 to

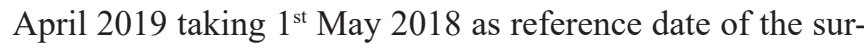
vey. Inhabited mainly by Mongoloid race, the study population is Indian easternmost State internationally bordering with Myanmar. The empirical data is analysed with SPSS vs 23. Though the term unwanted birth is generally defined to be the birth over the number of children a woman reported as her ideal number, a woman having at least $3^{\text {rd }}$ live birth is treated to have unwanted birth in the present research.

In addition to the classical t-test, binary logistic regression models are adopted to examine the impacts of socio-demographic factors of unwanted fertility. The dependent variable is dichotomous defined as 1 (one) if the woman has at least $3^{\text {rd }}$ live birth transition and 0 , otherwise say the women have at most two live births. The independent variables are social class (tribal $=1$, non-tribal $=0$ ), education, income, age at menarche, age at marriage, mother's age at $2^{\text {nd }}$ delivery, desire number of the son (son preference), sex of $2^{\text {nd }}$ live birth (male $=1$, female $=0$ ) and status of sterilization (wife is sterilized $=1$, otherwise $=0$ ). Among the variables, age, income and son preference have their quantitative values and hence no difficulties of measurement. For categorical variables - social class, sex and status of sterilization, a binary dummy variable $(0,1)$ is utilized. Taking education as an ordinal variable, it is measured by levels as Illiterate $=1$, under matriculate $=2$, matriculate $=3$, ten plus two $=4$, and graduate and above $=5$. The effects of the causal factors are comparatively explained in terms of their odds ratios (OR: $\left.\mathrm{e}^{\mathrm{b}}\right)$.

\section{RESULTS}

The fertility of tribal women (3.1) is found to be higher $(\mathrm{P}<0.01)$ than that of non-tribal women (2.6) while the overall mean fertility is 2.9 in the population. The starting event of the natural reproductive period, age at menarche varies significantly within the two social classes of tribal (12.9 years) and non-tribal (13.1 years) (Table - 1). The current fertility differential might be linked with significantly lower $(\mathrm{P}<0.05)$ age at marriage of tribal women (24 years) from non-tribal (25 years) and son preference as a parameter of family setups (tribal:1.9>non-tribal:1.7; $\mathrm{P}<0.05$ ). Here, the number of pregnancies is higher in non-tribal (3.5) than tribal (3.3) but it is inversely associated with the fertility of non- tribal (2.6) which is lower than tribal (3.1). It may perhaps be associated with fetal death and abortion. The child mortality rate is also higher in tribal women (son: $0.10 \pm 0.37$ and daughter: $0.06 \pm 0.27$ ) than that of non-tribal (son: $0.07 \pm 0.29$, daughter: $0.05 \pm 0.28)$.

Out of the total pregnancies, a woman has about $11 \%$ abortion of which the tribal share only $4.2 \%$ and non-tribal $17.3 \%$. It is estimated from the average number of abortions is $0.37 \pm 0.70$ correspondings to the number of pregnancies, $3.39 \pm 1.67$. While the average number of abortions per tribal woman is $0.14 \pm 0.40$, the corresponding figure of the nontribal woman is $0.60 \pm 0.84$. Thus, the rate of abortion for tribal women is significantly lower than that of non-tribal $(\mathrm{P}<0.01)$. When the duration of PPA for first birth is 4.96 months for all subjects, tribal women have significantly shorter 3.77 months than that non-tribal (6.17). Irrespective of parity, the PPA for last birth in tribal women (4.41) is also shorter $(\mathrm{P}<0.01)$ than non-tribal women $(6.23)$. As the last event of women's reproductive span, age at menopause (taking from 34 women with tribal: $47 \%$ and non-tribal: $53 \%$ ) is observed to be 47.5 years, it is significantly earlier $(\mathrm{P}<0.05)$ in tribal women (46.4 years) than non-tribal women (48.5 years). Because of these indicators, tribal couples may be observed far lagging behind the prevalence of birth control practices used by non-tribal couples in the population.

Of the 1152 subjects, 551 women (48\%) are found to have their third birth in the population. A binary logistic regression analysis on the phenomenon ( 1 if at least $3^{\text {rd }}$ birth occurred, 0 otherwise) is carried out to identify the determinants thereof. Firstly, simple logistic regressions of each model with only one independent variable are fitted. Of the ten variables, seven ones are found high significant $(\mathrm{P}<0.01)$. They are social class (tribal/ non-tribal), education of husband, education of wife, age at marriage of husband, age at marriage of the wife, mother's age at $2^{\text {nd }}$ delivery and desire number of the son (Table - 2). Irrespective of the effects of other variables, tribal women have a high chance $(\mathrm{P}<0.01)$ of having unwanted fertility. It indicates that tribal women have a $79 \%$ more chance of occurring the event than non-tribal (OR:1.79). To each advancement of one level, wife's education (OR:0.92) can prevent $8 \%(\mathrm{P}<0.01)$ chance from the $3^{\text {rd }}$ birth transition which is more effective than of husband (6\%). Similarly, the chance of $3^{\text {rd }}$ birth transition is reduced by $14 \%$ to one year increment in age at marriage of wife which is $7 \%$ in case of husband ( $\mathrm{OR}=0.93)$.

In multiple logistic regression models, only three out of ten variables can be detected to have significant impacts on unwanted fertility. The significant indicators are mother's age at $2^{\text {nd }}$ delivery $(\mathrm{P}<0.01, \mathrm{OR}=0.83)$, son preference $(\mathrm{P}<0.01$, $\mathrm{OR}=3.95)$ and sex of $2^{\text {nd }}$ live birth $(\mathrm{P}<0.05, \mathrm{OR}=0.55)$ (Table-3). Mother's age at $2^{\text {nd }}$ delivery and sex (male) of $2^{\text {nd }}$ live birth are negatively as well as significantly associated 
with the phenomenon. But, the behavioural factor says son preference is positively and highly significantly related to unwanted fertility. In the stepwise method, the determinants of unwanted fertility are found to be five factors - son preference, mother's age at $2^{\text {nd }}$ delivery, husband education, sex of $2^{\text {nd }}$ birth and status of sterilization (Table - 4). In other words, these five variables are identified to be the elements of the best set of unwanted fertility in the population.

In the last model, the risk of having unwanted fertility can significantly be reduced $(\mathrm{P}<0.01)$ by $6 \%$ as the advancement of one level in the husband's education (OR: 0.94). When one year advance in age at second delivery, the women can be free of $12 \%$ from the risk in the sense that at an average a woman has $12 \%$ more risk of being unwanted fertility with one year earlier of her age at delivery of second birth $(\mathrm{P}<0.01, \mathrm{OR}=0.82)$. A high risk of 3.7 times the chance of unwanted fertility is also observed to each increment in the couple's desire number of the son $(\mathrm{P}<0.01, \mathrm{OR}=3.74)$ when joint effects of the other four factors in the last model is typically controlled. This ill habit of son preference effect is again emphasized that high risk $(\mathrm{P}<0.01)$ of $3^{\text {rd }}$ birth is found to be $45 \%(\mathrm{OR}=0.55)$ in the previous $2^{\text {nd }}$ child is female than that of male. When controlling four factors namely desire level of the son, mother age at $2^{\text {nd }}$ delivery, education of husband and sex of $2^{\text {nd }}$ live birth, the chance of having unwanted fertility can be reduced by $89 \%(\mathrm{P}<0.01)$ if the mother has been sterilized $(\mathrm{OR}=0.19)$.

\section{DISCUSSION}

In simple models, seven factors viz., tribal/ non-tribal, couple's educational level, ages at marriage, age at $2^{\text {nd }}$ delivery and son preference have their highly significant contribution on unwanted fertility. Three variables say the age at second delivery, son preference and sex of second birth is found significant in the multiple logistic regression models. In the stepwise method, five factors can here be confirmed to be determinants of unwanted fertility. These are son preference, age at $2^{\text {nd }}$ delivery, husband education, sex of $2^{\text {nd }}$ live birth and status of sterilization. The findings support the view that in many Indian societies as the couples are educated, eagerness to restrict the family size increases. The husband education plays a more significant role in preventing unwanted fertility than that of their wives counterparts. It indicated that the husband's education has more associated with decisiontaking birth stopping particularly of $3^{\text {rd }}$ birth. These effects may include delaying the mother's age at $2^{\text {nd }}$ delivery, reducing son preference and other attitudes towards family limitations. It is incorporated with findings of Yadava and Sharma and Vignoli. ${ }^{7}{ }^{8}$ In the last fitted model, son preference is found to be a highly influential factor in the $3^{\text {rd }}$ birth phe- nomenon. It is again supported by the past studies conducted in Manipur (India). ${ }^{9}{ }^{10}$ It is also found in many developing countries that reproductive behaviours are strongly associated with the sex of the surviving children. ${ }^{11,12,13}$

\section{CONCLUSIONS}

In this empirical study, five factors viz., son preference, age at $2^{\text {nd }}$ delivery, husband education, sex of $2^{\text {nd }}$ birth and sterilization have been detected to be the main causes of unwanted fertility in tribal-dominated rural areas of Manipur valley, the Indian easternmost state internationally bordering with Myanmar. Possible efforts may be given to improve the specified parameters to have the national goal of population stabilization under the united nation's sustainable development goals (SDGs).

\section{Conflict of Interest: None}

\section{Source of Interest: None}

Author contribution: Sharat Singh- Manuscript preparation Sundari Devi- Dada Collection

\section{REFERENCES}

1. Nanda S. Cultural determinants of human fertility: A study of tribal population in Orissa. Anthropol. 2005; 7(3): 221-227.

2. Saha KB, Verma S. High fertility among scheduled tribes of Madhya Pradesh. Indian J Med Res. 2006; 123: 89-90.

3. IIPS, ICF. National Family Health Survey (NFHS-4) 2015-16 2017, Mumbai, India.

4. Nath DC, Deka AK. The importance of a son in a traditional society: How elderly parents see it? Demo Ind. 2004; 33(1): 33-46.

5. Nath DC, Leonetti DL. Correlates of coital patterns in a traditional Indian society. Dynamics of population change (Emerging issues of $21^{\text {st }}$ Century). Shipra Publication, Delhi. 2001: 57-67.

6. IIPS. National Family Health Survey. 2005-06, Manipur, 2008.

7. Yadava RC, Sharma SS.Closed birth interval versus most recent closed birth intervals. Demo Ind. 2004; 33(2): 249-263.

8. Vignoli D. Fertility change in Egypt: From the second to third birth. MPIDR Working Paper 2006-011.

9. Singh NS, Narendra RK. Determinants of waiting time to conception in Manipuri women. Kuwait Med J. 2007; 39(1): 39-43.

10. Singh NS, Sanajaoba N, Narendra RK. Survival analysis of duration of waiting time to conception. Elec J Appl Stat Appl. 2011; 4(2): 144-154.

11. Hussain R, Fikree FF, Berendes HW. The role of son preference in reproductive behaviour in Pakistan. Bull World Health Org. 2000; 78(3): 379-388.

12. Youssef RM. Duration and determinants of interbirth interval: Community-based survey of women on Southern Jordan. East Medit Health J. 2005; 11(4): 559-572.

13. Khawaja M, Randall A. Intifada Palestinian fertility and women's education. Genus. 2006; LXII (1): 21-51. 
Table 1: Differential of fertility indicators according to tribal/non-tribal class

\begin{tabular}{|c|c|c|c|c|}
\hline Indicators & Social class & Mean \pm S.D & $\begin{array}{l}95 \% \text { CI for Mean } \\
\text { (Lower, Upper) }\end{array}$ & P-value for t-test \\
\hline \multirow[t]{3}{*}{ Current Fertility } & Non-tribal & $2.59^{ \pm 1.50}$ & $(2.48,2.70)$ & $\mathrm{P}<0.01$ \\
\hline & Tribal & $3.11 \pm 1.40$ & $(3.01,3.22)$ & \\
\hline & Total & $2.85^{ \pm 1.47}$ & $(2.77,2.93)$ & \\
\hline \multirow[t]{3}{*}{ Age at menarche } & Non-tribal & $13.13^{ \pm 1.31}$ & $(13.03,13.23)$ & $\mathrm{P}<0.01$ \\
\hline & Tribal & $12.90 \pm 1.08$ & $(12.82,12.98)$ & \\
\hline & Total & $13.01 \pm 1.21$ & $(12.95,13.08)$ & \\
\hline \multirow[t]{3}{*}{ Age at marriage (wife) } & Non-tribal & $24.96 \pm 4.76$ & $(24.61,25 \cdot 32)$ & $\mathrm{P}<0.05$ \\
\hline & Tribal & $24.25^{ \pm} 4.78$ & $(23.89,24.61)$ & \\
\hline & Total & $24.61 \pm 4.78$ & $(24.35,24.86)$ & \\
\hline \multirow[t]{3}{*}{ Desire no. of son } & Non-tribal & $1.73^{ \pm 0.48}$ & $(1.69,1.76)$ & $\mathrm{P}<0.01$ \\
\hline & Tribal & $1.92 \pm 0.37$ & $(1.89,1.95)$ & \\
\hline & Total & $1.82 \pm 0.44$ & $(1.80,1.85)$ & \\
\hline \multirow[t]{3}{*}{ No. of deceased son } & Non-tribal & $0.07 \pm 0.29$ & $(0.04,0.09)$ & $\mathrm{P}>0.05$ \\
\hline & Tribal & $0.10 \pm 0.37$ & $(0.07,0.13)$ & \\
\hline & Total & $0.08 \pm 0.33$ & $(0.06,0.10)$ & \\
\hline \multirow[t]{3}{*}{ No. of deceased daughter } & Non-tribal & $0.05^{ \pm 0.28}$ & $(0.03,0.07)$ & $\mathrm{P}>0.05$ \\
\hline & Tribal & $0.06 \pm 0.27$ & $(0.04,0.08)$ & \\
\hline & Total & $0.06 \pm 0.27$ & $(0.04,0.07)$ & \\
\hline \multirow[t]{3}{*}{ No. of stillbirth } & Non-tribal & $0.10 \pm 0.79$ & $(0.04,0.16)$ & $\mathrm{P}<0.01$ \\
\hline & Tribal & $0.01 \pm 0.12$ & $(0.01,0.02)$ & \\
\hline & Total & $0.06 \pm 0.56$ & $(0.03,0.09)$ & \\
\hline \multirow[t]{3}{*}{ No. of miscarriage } & Non-tribal & $0.14^{ \pm 0.41}$ & $(0.11,0.17)$ & $\mathrm{P}>0.05$ \\
\hline & Tribal & $0.12 \pm 0.34$ & $(0.10,0.15)$ & \\
\hline & Total & $0.13^{ \pm 0.38}$ & $(0.11,0.15)$ & \\
\hline \multirow[t]{3}{*}{ No. of abortion } & Non-tribal & $0.60 \pm 0.84$ & $(0.54,0.67)$ & $\mathrm{P}<0.01$ \\
\hline & Tribal & $0.14 \pm 0.40$ & $(0.11,0.17)$ & \\
\hline & Total & $0.37^{ \pm 0.70}$ & $(0.33,0.41)$ & \\
\hline \multirow[t]{3}{*}{ No. of pregnancies } & Non-tribal & $3.46 \pm 1.88$ & $(3.32,3.60)$ & $\mathrm{P}>0.05$ \\
\hline & Tribal & $3.32 \pm 1.42$ & $(3.22,3.43)$ & \\
\hline & Total & $3 \cdot 39^{ \pm 1.67}$ & $(3.30,3.48)$ & \\
\hline \multirow[t]{3}{*}{ Age at the first delivery } & Non-tribal & $25.19^{ \pm} 4.29$ & $(24.86,25.51)$ & $\mathrm{P}<0.05$ \\
\hline & Tribal & $25.79^{ \pm} 4.44$ & $(25.46,26.13)$ & \\
\hline & Total & $25 \cdot 49^{ \pm} 4.37$ & $(25.26,25.73)$ & \\
\hline \multirow{3}{*}{$\begin{array}{l}\text { Duration (in mth) of PPA } \\
\text { for the first birth }\end{array}$} & Non-tribal & $6.17 \pm 4.63$ & $(5.81,6.52)$ & $\mathrm{P}<0.01$ \\
\hline & Tribal & $3 \cdot 77^{ \pm 2.82}$ & $(3.56,3.99)$ & \\
\hline & Total & $4.96 \pm_{4.00}$ & $(4.74,5.17)$ & \\
\hline \multirow{3}{*}{$\begin{array}{l}\text { Duration (in mth) of PPA } \\
\text { for last birth }\end{array}$} & Non-tribal & $6.23^{ \pm 3.96}$ & $(5.93,6.53)$ & $\mathrm{P}<0.01$ \\
\hline & Tribal & $4.41 \pm 2.61$ & $(4.22,4.61)$ & \\
\hline & Total & $5 \cdot 32 \pm 3 \cdot 47$ & $(5.13,5.50)$ & \\
\hline \multirow[t]{3}{*}{ Age at last delivery } & Non-tribal & $30.34^{ \pm} 4.57$ & $(29.92,30.76)$ & $\mathrm{P}<0.01$ \\
\hline & Tribal & $32.85^{ \pm} 4.57$ & $(32.50,33.19)$ & \\
\hline & Total & $31.60 \pm 5.19$ & $(31.32,31.88)$ & \\
\hline \multirow[t]{3}{*}{ Age at menopause } & Non-tribal & $48.5^{ \pm 1} \mathbf{1 . 7 4}$ & $(47.70,49.32)$ & $\mathrm{P}<0.05$ \\
\hline & Tribal & $46.39^{ \pm 3.55}$ & $(44.62,48.15)$ & \\
\hline & Total & $47 \cdot 1^{ \pm 2.91}$ & $(46.55,48.46)$ & \\
\hline
\end{tabular}


Table 2: OR of variables on $3^{\text {rd }}$ births transition in simple logistic regressions

\begin{tabular}{lccc} 
Variable & $\mathbf{b}$ & OR $(95 \% \mathrm{CI})$ & P-value \\
Social class - tribal/non-tribal & 0.58 & $1.79(1.21,2.64)$ & $<0.01$ \\
Education of husband & -0.06 & $0.94(0.92,0.97)$ & $<0.01$ \\
Education of wife & -0.08 & $0.92(0.90,0.95)$ & $<0.01$ \\
Family income & 0.01 & $1.01(0.99,1.04)$ & $>0.05$ \\
Age at marriage (husband) & -0.07 & $0.93(0.90,0.96)$ & $<0.01$ \\
Age at marriage (wife) & -0.15 & $0.86(0.83,0.90)$ & $<0.01$ \\
Age at $2^{\text {nd }}$ delivery & -0.13 & $0.87(0.83,0.93)$ & $<0.01$ \\
Desire number of son & 1.99 & $7.36(4.34,12.48)$ & $<0.01$ \\
Sex of $2^{\text {nd }}$ birth & -0.22 & $0.80(0.52,1.25)$ & $>0.05$ \\
Status of sterilization & -0.71 & $0.49(0.17,1.44)$ & $>0.05$ \\
\hline
\end{tabular}

Table 3: OR of variables on $3^{\text {rd }}$ births transition in multiple logistic regressions

\begin{tabular}{lccc} 
Variable & $\mathbf{b}$ & OR $(95 \% \mathrm{CI})$ & P-value \\
Social class - tribal/non-tribal & 0.12 & $1.103(0.56,2.18)$ & $>0.05$ \\
Education of husband & -0.04 & $0.957(0.91,1.01)$ & $>0.05$ \\
Education of wife & -0.02 & $0.976(0.93,1.02)$ & $>0.05$ \\
Family income & 0.01 & $1.003(0.97,1.04)$ & $>0.05$ \\
Age at marriage (husband) & 0.02 & $1.016(0.96,1.07)$ & $>0.05$ \\
Age at marriage (wife) & 0.07 & $1.069(0.95,1.21)$ & $>0.05$ \\
Age at $2^{\text {nd }}$ delivery & -0.18 & $0.832(0.74,0.94)$ & $<0.01$ \\
Desire number of son & 1.37 & $3.949(1.91,8.16)$ & $<0.01$ \\
Sex of $2^{\text {nd }}$ birth & -0.60 & $0.549(0.32,0.95)$ & $<0.05$ \\
Status of sterilization & -1.48 & $0.229(0.04,1.33)$ & $>0.05$ \\
Constant & 2.17 & 8.783 & $>0.05$ \\
\hline
\end{tabular}

Table 4: Odds Ratios of variables on $3^{\text {rd }}$ birth transition in stepwise logistic regression

\begin{tabular}{|c|c|c|c|c|}
\hline Step & Variable & $\mathbf{b}$ & OR $(95 \% \mathrm{CI})$ & P-value \\
\hline \multirow[t]{2}{*}{1} & Desire number of son & 1.61 & $4.99(2.58,9.67)$ & $<0.01$ \\
\hline & Constant & -2.34 & 0.10 & $<0.01$ \\
\hline \multirow[t]{3}{*}{2} & Age at $2^{\text {nd }}$ delivery & -0.11 & $0.89(0.84,0.95)$ & $<0.01$ \\
\hline & Desire number of son & 1.42 & $4.14(2.09,8.22)$ & $<0.01$ \\
\hline & Constant & 1.43 & 4.18 & $>0.05$ \\
\hline \multirow[t]{4}{*}{3} & Education of husband & -0.05 & $0.95(0.91,0.98)$ & $<0.01$ \\
\hline & Age at $2^{\text {nd }}$ delivery & -0.11 & $0.90(0.85,0.95)$ & $<0.01$ \\
\hline & Desire number of son & 1.43 & $4.20(2.11,8.37)$ & $<0.01$ \\
\hline & Constant & 1.59 & 4.92 & $>0.05$ \\
\hline \multirow[t]{5}{*}{4} & Education of husband & -0.06 & $0.94(0.91,0.98)$ & $<0.01$ \\
\hline & Age at $2^{\text {nd }}$ delivery & -0.12 & $0.89(0.84,0.94)$ & $<0.01$ \\
\hline & Sex of $2^{\text {nd }}$ live birth & -0.65 & $0.52(0.31,0.89)$ & $>0.05$ \\
\hline & Desire number of son & 1.47 & $4.33(2.14,8.77)$ & $<0.01$ \\
\hline & Constant & 2.16 & 8.70 & $>0.05$ \\
\hline
\end{tabular}


Table 4: (Continued)

\begin{tabular}{llccc} 
Step & Variable & b & OR $(95 \%$ CI $)$ & P-value \\
5 & Education of husband & -0.06 & $0.95(0.91,0.98)$ & $<0.01$ \\
Age at $2^{\text {nd }}$ delivery & -0.12 & $0.88(0.83,0.94)$ & $<0.01$ \\
Sex of $2^{\text {nd }}$ live birth & -0.60 & $0.55(0.32,0.94)$ & $<0.05$ \\
Desire number of son & 1.41 & $3.74(1.99,7.34)$ & $<0.01$ \\
Status of sterilization & -1.68 & $0.19(0.03,1.05)$ & $>0.05$ \\
Constant & 2.44 & 11.49 & $<0.05$ \\
\hline
\end{tabular}

